\title{
Production of concrete compatible biogranules for self-healing concrete applications
}

\author{
Merve Sonmez ${ }^{1}$, and Yusuf Cagatay Ersan ${ }^{1,2, *}$ \\ ${ }^{1}$ Abdullah Gul University, Department of Civil Engineering, TR-38080, Kayseri, Turkey \\ ${ }^{2}$ Hacettepe University, Department of Environmental Engineering, TR-06800, Ankara, Turkey
}

\begin{abstract}
Recently, cost-efficient nitrate reducing biogranules were suggested as an alternative to axenic microbial cultures for development of microbial self-healing concrete. In a marine environment, biogranule containing microbial self-healing concrete showed simultaneous self-healing of cracks and immunisation against rebar corrosion. Yet, information about the production strategy of these biogranules and their compatibility with a mortar matrix is limited. This study presents the production of biogranules and their compatibility with mortar specimens when incorporated at dosages between $0.36 \%$ to $4.30 \% \mathrm{w} / \mathrm{w}$ cement ( $0.25 \%$ to $3 \%$ of bacteria w/w cement). In-house produced biogranules composed of $70 \%$ bacteria and $30 \%$ of minerals w/w of biogranule were used for the compatibility tests. In test mortars, calcium formate (CF) and calcium nitrate $(\mathrm{CN})$ were used as regular nutrient admixtures, and nutrient content was set identical in every batch. Up to $2.9 \%$ incorporation, biogranules had no significant influence on the fresh properties of mortar. More than $2.9 \%$ incorporation caused poor workability and a 26\% decrease in 3-Day compressive strength of biomortar specimens. Overall, the biogranules produced are compatible with a cementitious matrix up to $2.9 \% \mathrm{w} / \mathrm{w}$ cement, and even up to $3.6 \%$ if early age strength is not essential, which makes biogranules one of the most compatible microbial healing agents among the suggested agents in the literature.
\end{abstract}

\section{Introduction}

The formation of microcracks is a prevalent issue in reinforced concrete structures, which requires continuous and delicate monitoring for detection, and labour intensive maintenance. Unless treated properly, microcracks can pave the way for reinforcement corrosion and compromise durability of the structures. In the last decade, significant effort was put on development of selfsensing and self-healing concrete in order to minimize external maintenance practices. Exploiting microbes and microbial induced calcium carbonate precipitation (MICP) can be mentioned among the popular self-healing concrete development strategies. Metabolic by-products (i.e. $\mathrm{CO}_{2}$ ) produced by heterotrophic microbes has appeared to be useful for creating an autonomous repair system in concrete, as microbially produced $\mathrm{CO}_{2}$ turns into $\mathrm{CO}_{3}{ }^{2-}$ (carbonate) in the alkaline environment of concrete and precipitates as $\mathrm{CaCO}_{3}$ (calcite) inside the cracks.

Various microbes have already been tested for the proof of the principle and several useful strains were identified for the development of microbial self-healing concrete (Table 1). Therefore, it is safe to claim that the proof and design stages of microbial self-healing concrete are almost over. Currently, the field requires optimization and improvement of the developed microbial self-healing concrete to enable cost-efficient upscaling of the technology. Therefore, economic feasibility, practicality of the proposed self-healing strategy and the delicacy of the microbial healing agent should be evaluated carefully. Moreover, the constraints for the dosages of typical components of microbial self-healing concrete (nutrients, protective carriers and microbial healing agents) should be determined.

One of the suggested microbial cultures for development of microbial self-healing concrete is granulated non-axenic culture, so called activated compact denitrifying core (ACDC) [1]. One of the advantages of granulated microbial cultures are their layered structure obtained with systematic placement of bacteria based on the required redox potentials of their metabolic activities [2]. ACDC biogranules were defined to have a core community composed of highly active nitrate reducing microbiome that were surrounded by aerobic bacteria, extracellular polymeric substances and calcium based minerals [1]. The layers surrounding the core community ensure the self-protection capability of ACDC biogranules and avoid the need for protective carriers such as porous aggregates or microcapsules [3], which make it advantageous over axenic cultures in terms of practicality, shelf-life and cost-efficiency. ACDC biogranules specifically granulated for concrete application were determined to be compatible with a cementitious matrix and are useful for crack healing in concrete at a bacteria dosage of $0.50 \% \mathrm{w} / \mathrm{w}$ cement $[1,4]$. Moreover, at the same dosage, ACDC granules simultaneously inhibit reinforcement bar corrosion, by 
producing the anodic corrosion inhibitor $\mathrm{NO}_{2}{ }^{-}$, and heal a $300-\mu \mathrm{m}$-wide crack in 28 days in marine-similar conditions [5]. The former provides a bio-based alternative to the use of chemical corrosion inhibitors and enhances the sustainability of the cementitious materials. The added corrosion inhibition function may also accelerate the transition of the technology from concept to market.

Table 1 Bacteria successfully applied and suggested for development of microbial self-healing concrete

\begin{tabular}{|c|c|c|}
\hline Study & $\begin{array}{l}\text { Bacterial strain - } \\
\text { pathway }\end{array}$ & $\begin{array}{l}\text { Protective } \\
\text { carrier }\end{array}$ \\
\hline $\begin{array}{l}\text { Wiktor and } \\
\text { Jonkers [6] }\end{array}$ & $\begin{array}{l}\text { Bacillus } \\
\text { alkalinitrilicus } \\
\text { aerobic oxidation of } \\
\text { organic carbon }\end{array}$ & $\begin{array}{l}\text { Light weight } \\
\text { aggregates }\end{array}$ \\
\hline $\begin{array}{l}\text { Wang et al. } \\
{[7,8]}\end{array}$ & $\begin{array}{l}\text { Bacillus sphaericus - } \\
\text { urea hydrolysis }\end{array}$ & $\begin{array}{l}\text { Hydrogels } \\
\text { Microcapsules }\end{array}$ \\
\hline \multirow[b]{2}{*}{$\begin{array}{l}\text { Silva } \\
\text { al. }[9,10]\end{array}$} & $\begin{array}{l}\text { Bacillus sphaericus - } \\
\text { urea hydrolysis }\end{array}$ & $\begin{array}{l}\text { Diatomaceous } \\
\text { earth }\end{array}$ \\
\hline & $\begin{array}{lr}\text { Cyclic } & \text { EnRiched } \\
\text { Ureolytic } & \text { Powder } \\
\text { (CERUP) } & \end{array}$ & $\begin{array}{l}\text { Self-protected } \\
\text { culture }\end{array}$ \\
\hline \multirow[b]{2}{*}{$\begin{array}{l}\text { Ersan et al. } \\
{[1,11]}\end{array}$} & $\begin{array}{l}\text { Diaphorobacter } \\
\text { nitroreducens - } \\
\text { anoxic oxidation of } \\
\text { organic carbon } \\
\text { (nitrate reduction } \\
\text { metabolism) }\end{array}$ & $\begin{array}{l}\text { Granular } \\
\text { activated } \\
\text { carbon }\end{array}$ \\
\hline & $\begin{array}{l}\text { Activated compact } \\
\text { denitrifying core } \\
\text { (ACDC) } \\
\text { anoxic oxidation of } \\
\text { organic carbon } \\
\text { (nitrate reduction } \\
\text { metabolism) }\end{array}$ & $\begin{array}{l}\text { Self-protected } \\
\text { granular } \\
\text { culture }\end{array}$ \\
\hline $\begin{array}{l}\text { Palin et al. } \\
{[12]}\end{array}$ & $\begin{array}{l}\text { Bacillus halmapalus- } \\
\text { aerobic oxidation of } \\
\text { organic carbon }\end{array}$ & $\begin{array}{l}\text { Calcium } \\
\text { alginate beads }\end{array}$ \\
\hline $\begin{array}{l}\text { Tziviloglou } \\
\text { et al. [13] }\end{array}$ & $\begin{array}{l}\text { Bacillus cohnii - } \\
\text { aerobic oxidation of } \\
\text { organic carbon }\end{array}$ & Expanded clay \\
\hline $\begin{array}{l}\text { Khaliq and } \\
\text { Ehsan [14] }\end{array}$ & $\begin{array}{l}\text { Bacillus subtilis - } \\
\text { aerobic oxidation of } \\
\text { organic carbon }\end{array}$ & $\begin{array}{l}\text { Light weight } \\
\text { aggregates }\end{array}$ \\
\hline $\begin{array}{l}\text { Davies et al. } \\
{[15]}\end{array}$ & $\begin{array}{l}\text { Bacillus } \\
\text { pseudofirmus } \\
\text { aerobic oxidation of } \\
\text { organic carbon }\end{array}$ & $\begin{array}{l}\text { Expanded } \\
\text { perlite }\end{array}$ \\
\hline
\end{tabular}

Owing to the aforementioned advantages, ACDC biogranules are worth investigating further in detail for up-scaling of microbial self-healing concrete technology. Concrete admixtures should be evaluated for their compatibility with the cementitious matrix at different dosages and such information about the compatibility of ACDC biogranules remains unknown. Therefore, this study aims to define the dosage constraints for the use of
ACDC for development of microbial self-healing concrete by evaluating the fresh and hardened properties of various cementitious composites containing $0.36 \%$ to $4.30 \%$ of ACDC biogranules w/w cement $(0.25 \%$ to $3 \%$ of bacteria w/w cement)

\section{Materials and methods}

\subsection{Cultivation of self-protected biogranules}

Biogranules with an activated denitrifying core were used as the microbial agent in tested biomortar mixtures. Fresh biogranules were produced in a cylindrical sequencing batch reactor (effective $\mathrm{h}=60 \mathrm{~cm}, \varnothing=12.4 \mathrm{~cm}$ and $50 \%$ volume exchange ratio). Old dry biogranules, which had been cultivated in a previous study $[1,4]$ were ground to a size of less than $0.212 \mathrm{~mm}$ and used as seed for cultivation of the fresh biogranules in this study. The bioreactor was operated with four batch-cycles/day, and each cycle consisted of three periods. The period sequence was set as 180 minutes of anoxic period followed by $175-180$ minutes of aerobic period and finally 0-5 minutes of settling period. Anoxic period was obtained by 120 minutes simultaneous fill/draw period with an upflow influent flow rate of $0.5 \mathrm{~mL} / \mathrm{s}$ and an extra 60 minutes of sole anoxic period. The aerobic period was obtained by aeration with an upflow air velocity of $0.8 \mathrm{~cm} / \mathrm{s}$.

The reactor was fed with an alkaline minimal nutrient medium (Table 2) to enable cultivation of microorganisms, resilient enough to survive the alkaline and micronutrient deficient concrete environment. The $\mathrm{pH}$ of the feed solution was set to 10.2 by using $10 \mathrm{M}$ $\mathrm{NaOH}$ solution.

Table 2. Composition of the minimal nutrient medium prior to $\mathrm{pH}$ adjustment to 10.2

\begin{tabular}{cc}
\hline Compound & Concentration $(\mathbf{m g} / \mathbf{L})$ \\
\hline $\mathrm{NaHCOO}$ & 3239 \\
$\mathrm{NaNO}_{3}$ & 331 \\
$\mathrm{Ca}\left(\mathrm{NO}_{3}\right)_{2}$ & 267 \\
$\mathrm{MgSO}_{4} .7 \mathrm{H}_{2} \mathrm{O}$ & 89 \\
$\mathrm{KH}_{2} \mathrm{PO}_{4}$ & 13 \\
\hline
\end{tabular}

At the end of 2 months of operation, biogranules occupied $90 \%$ of the overall bioreactor content and thus we started to harvest biogranules for the compatibility tests. Granule harvesting was repeated biweekly for the following 5 months. Harvested biogranules were dried in a ventilated electric oven at $60^{\circ} \mathrm{C}$ for 48 hours. Dry granules were further allocated into three portions based on their particle sizes $(0.45$ to $2 \mathrm{~mm})$ and stored in closed containers at room temperature. The allocated portions had sizes of 0.45 to $0.85 \mathrm{~mm}, 0.85$ to $1 \mathrm{~mm}$ and 1 to $2 \mathrm{~mm}$. Dry granules having particle sizes either more than $2 \mathrm{~mm}$ or less than $0.45 \mathrm{~mm}$ were returned to the bioreactor.

The bacteria content of the biogranules was determined by using the ratio of volatile suspended solids (VSS) to total suspended solids (TSS). Bacteria and biogranule contents presented in this study represent the 
VSS and TSS, respectively. VSS and TSS analyses were conducted according to the standard methods [16].

\subsection{Chemical admixtures serving as nutrients for microbial induced $\mathrm{CaCO}_{3}$ precipitation}

As mentioned above, the investigated biogranules use anoxic oxidation of carbon via nitrate reduction metabolism for both energy generation and growth. Therefore, to induce $\mathrm{CaCO}_{3}$ precipitation, the biogranules require an organic carbon source as an electron donor and a nitrate source as an electron acceptor. Commercially available concrete admixtures, namely, calcium formate (CF) and calcium nitrate $(\mathrm{CN})$, were used in mortar mixtures as sources of electron donor and electron acceptor, respectively. Throughout the experiments, the nutrient contents of different biomortars were kept identical to clearly distinguish the compatibility of biogranules with the mortar matrix.

\subsection{Testing compatibility of ACDC biogranules with mortar}

\subsubsection{Preparation of the mortar mixes}

The biomortar specimens containing identical amounts of nutrients and various amount of bacteria were prepared according to the standard procedure described in EN 1961. DIN EN 196-1 standard sand (1350 g), CEM I 42.5R cement $(450 \mathrm{~g})$ and, tap water $(225 \mathrm{~g})$ were used as structural ingredients with a weight ratio of $3: 1: 0.5$. The $\mathrm{CF}$ and $\mathrm{CN}$ contents of the biomortars were $5.00 \%$ (22.50 g) and $2.00 \%(9.00 \mathrm{~g}) \mathrm{w} / \mathrm{w}$ cement (Table 3). These admixtures' percentages were previously optimized by considering the effect of their weight percentages on the bioavailability of nutrients as well as the fresh and hardened properties of mortar [17].

Table 3. Composition of the tested mortar and biomortar mixtures

\begin{tabular}{cccc}
\hline $\begin{array}{c}\text { Mortar } \\
\text { mixtures }\end{array}$ & $\begin{array}{c}\text { ACDC } \\
\text { Content (g) }\end{array}$ & CF (g) & CN (g) \\
\hline Reference & - & - & - \\
Control & - & 22.50 & 9.00 \\
Bio-0.25\% & 1.61 & 22.50 & 9.00 \\
Bio-0.50\% & 3.21 & 22.50 & 9.00 \\
Bio-0.75\% & 4.82 & 22.50 & 9.00 \\
Bio-1.00\% & 6.43 & 22.50 & 9.00 \\
Bio-1.50\% & 9.64 & 22.50 & 9.00 \\
Bio-2.00\% & 12.86 & 22.50 & 9.00 \\
Bio-2.50\% & 16.07 & 22.50 & 9.00 \\
Bio-3.00\% & 19.28 & 22.50 & 9.00 \\
\hline 1 Sand:cement:water contents $1350 \mathrm{~g}: 450$ g:225 g \\
were fixed in all mixes and the percentages represent \\
wt bacteria/wt cement in biomortars. \\
\hline
\end{tabular}

${ }^{2}$ ACDC: Biogranules $(70 \%$ bacteria $+30 \%$ minerals $)$ with an activated compact denitrifying core. $\mathrm{CF}$ : Calcium formate. $\mathrm{CN}$ : Calcium nitrate.

Together with a plain mortar mixture, hereafter referred to as reference, which didn't include microbial or chemical admixtures, a control mortar mixture that included chemical admixtures (5\% CF and $2 \% \mathrm{CN}$ ), and a series of biomortars with a bacteria content varying in the range of $0.25 \%$ to $3.00 \%$ were investigated (Table 3 ).

The particle size distribution of the incorporated dry biogranules, which varied between 0.45 to $2 \mathrm{~mm}$, were set identical in each biomortar mix. Accordingly, in each biomortar mix, $50 \%$ of the total biogranule content were between 1.00 to $2.00 \mathrm{~mm}$ in size, $35 \%$ of the total biogranule content were between 0.85 to $1 \mathrm{~mm}$ in size and $15 \%$ of the total biogranule content were between 0.45 to $0.85 \mathrm{~mm}$ in size (Table 4).

Table 4 Fixed size distribution of the dry biogranules prior to biomortar incorporation

\begin{tabular}{cccc}
\hline \multirow{2}{*}{$\begin{array}{c}\text { Mortar } \\
\text { mix }\end{array}$} & \multicolumn{3}{c}{$\begin{array}{c}\text { Size distribution of the incorporated } \\
\text { dry biogranules (g) }\end{array}$} \\
\cline { 2 - 4 } & $\begin{array}{c}\mathbf{0 . 4 5 - 0 . 8 5} \\
\text { mm }\end{array}$ & $\begin{array}{c}\mathbf{0 . 8 5 - 1 . 0 0} \\
\text { mm }\end{array}$ & $\begin{array}{c}\mathbf{1 . 0 0 - 2 . 0 0} \\
\text { mm- }\end{array}$ \\
\hline Bio-0.25\% & 0.24 & 0.56 & 0.81 \\
Bio-0.50\% & 0.48 & 1.12 & 1.61 \\
Bio-0.75\% & 0.72 & 1.69 & 2.41 \\
Bio-1.00\% & 0.97 & 2.25 & 3.21 \\
Bio-1.50\% & 1.45 & 3.37 & 4.82 \\
Bio-2.00\% & 1.93 & 4.50 & 6.43 \\
Bio-2.50\% & 2.41 & 5.62 & 8.04 \\
Bio-3.00\% & 2.89 & 6.75 & 9.64 \\
\hline
\end{tabular}

\subsubsection{Evaluation of the fresh mortar properties}

Throughout the experiments, fresh mortar properties were determined via setting test and flow table test. In order to evaluate the strength development of different biomortars, compressive strength tests were conducted on Day 3, Day 7 and Day 28.

Setting tests were performed based on the ASTMC807 standard by using automatic vicat equipment (Matest E044N Vicatronic, Italy). Based on ASTM C191-04a and NBN EN-1008 standards, 60 minutes and 90 minutes were set as the acceptable lower limit for initial setting and final setting times, respectively. In ASTM C191-04a, for a single operator within the laboratory, the standard deviation of setting time of hydraulic cement is given as 12 minutes for initial setting time and 20 minutes for the final setting time throughout the range of 49-202 minutes and 185-312 minutes, respectively. Since no standard value about the standard deviation of setting times of cement mortar is available, same standard deviations were used to identify significant differences between different biomortars tested in this study.

Flow table tests were conducted according to the NBN EN 1015-3 standard. Considering the NBN EN 1015-3 
standard, the maximum acceptable deviation between subjected specimen flow and the reference flow was determined as $10 \%$ for significance. Obtained data from these tests were used to determine the consistency and workability of different biomortars.

\subsubsection{Evaluation of the hardened mortar properties}

Compressive strength tests were conducted to evaluate the hardened properties of different mixtures and determine the strength development of different biomortars. Tests were conducted according to the ASTM C109 standard.

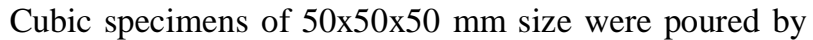
using cubic moulds and moulded specimens were stored in sealed bags for 24 hours. After demoulding, cubic specimens were stored again in sealed bags at room temperature until the test day. Specimens were tested via compressive strength testing machine with a maximum load capacity of $300 \mathrm{kN}$ (UTC-5700, Turkey) on Day 3, Day 7 and Day 28.

\section{Results and discussion}

\subsection{Properties of the obtained biogranules}

Fresh new biogranules with activated compact denitrifying core were successfully produced by using old dry biogranules (Figure 1).

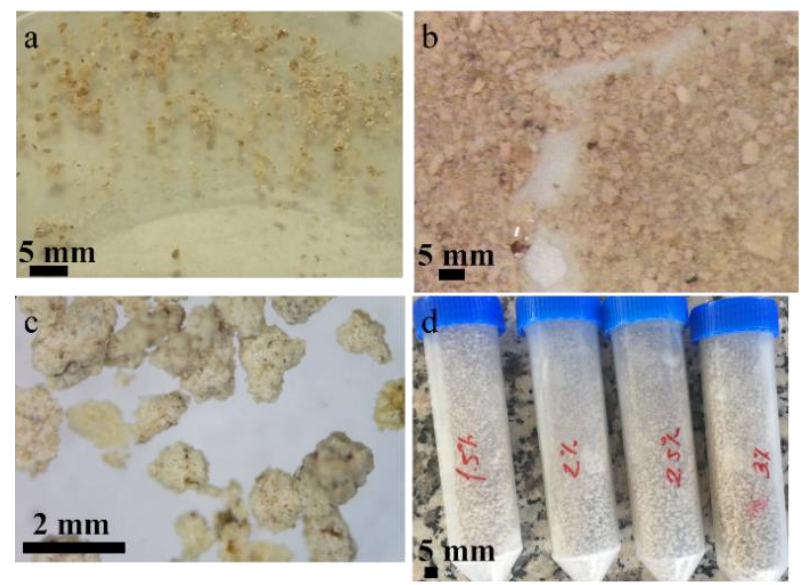

Figure 1 Successful production of biogranules with activated compact denitrifying core (ACDC). Old dry ACDC used as seed for production of fresh ACDC (a); fresh ACDC on a tray prior to drying (b); dry fresh ACDC of 1-2 $\mathrm{mm}$ in size under microscope (c); dry ACDC ready for mortar incorporation (d).

Biogranules produced in this study showed similarities to the ones produced in previous studies. Solid matter analyses (VSS:TSS ratio) revealed that, by weight, 70\% and $30 \%$ of the biogranules were bacteria and inorganic matter, respectively, which was similar to the composition of previously produced biogranules [1,4]. Therefore, it can be claimed that the production of ACDC biogranules with a similar organic and inorganic matter content is possible even if the operational parameters slightly vary. Yet, the exact microbial composition of the fresh biogranules was unknown, which prevents their further comparison with the previously produced ACDC biogranules.
The size distribution of the harvested granules, after drying at $60^{\circ} \mathrm{C}$, are given in Figure 2. Since, granules having particle sizes between 0.45 and $2 \mathrm{~mm}$ were used for the tests, approximately $34 \%$ of the harvested granules were not useful (Figure 2). The least proportion of the dry granules had particle sizes larger than $2.00 \mathrm{~mm}$ (Figure 2). Approximately $30 \%$ of the dry granules were between 1.00 to $2.00 \mathrm{~mm}$ in size, which corresponds to almost half of the testable dry granules (Figure 2).

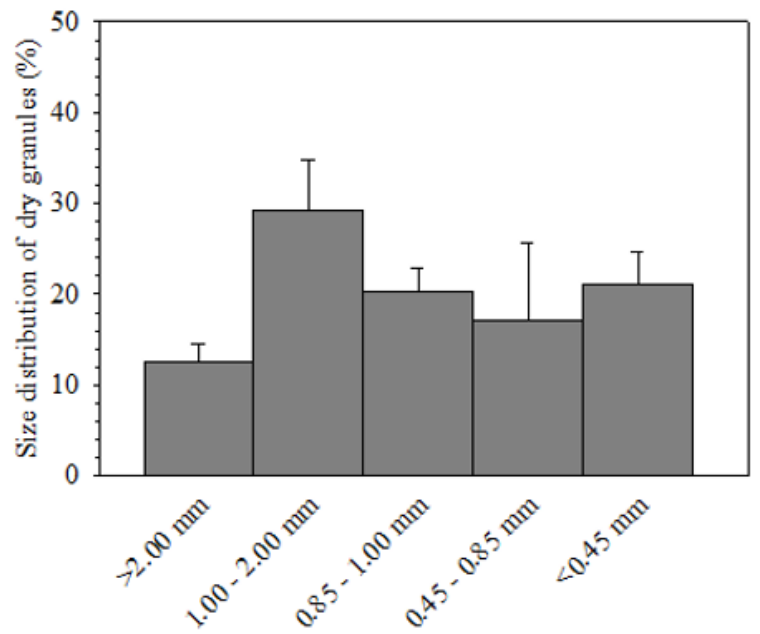

Figure 2 Particle size distribution of the dry fresh ACDC biogranules. Error bars represent the standard deviation of the mean of different harvests $(n=10)$

\subsection{Maximum tolerable biogranule dosage in fresh mortar}

The effect of biogranules on fresh cement mortar was investigated by comparing setting and flow behaviour of different biomortar mixes with reference and control mortars. Obtained setting times and flow data for the tested fresh mortar mixes are given in Figure 3 and Table 5 , respectively.

Both initial and final setting times of control mortar and all of the tested biomortars were significantly different from the reference mortar according to the defined standard deviation (12 minutes for initial setting and 20 minutes for final setting) in ASTM C191-04a. Initial and final setting values for control mixture were 55 \pm 12 minutes and $172 \pm 20$ minutes, respectively. These findings were in good agreement with the previous findings where initial and final setting times of CF5.00$\mathrm{CN} 2.00$ mixture were found as $65 \pm 12$ minutes and 146 \pm 20 minutes [17].

Incorporation of bacteria, in the form of ACDC, with a dosage up to $2.50 \% \mathrm{w} / \mathrm{w}$ cement did not cause any significant change in the setting times of the fresh cement mortar when compared to the control mixture. When the dosage was increased to $3.00 \%$, a significant decrease occurred in the initial setting time. The recorded initial setting time for the corresponding biomortar mix was 34 \pm 12 minutes, which was far from the acceptable initial setting limit (60 minutes) defined in ASTM C191-04a.

In all biomortar mixtures, ACDC biogranules had no influence on the final setting time when compared to the 
control mortar. These results were in parallel with the previous observation.

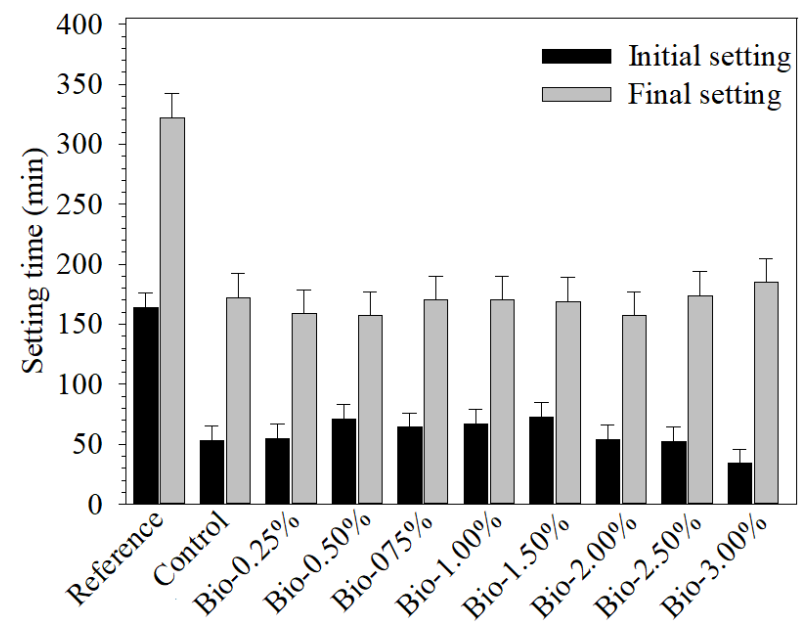

Figure 3 Variation of initial and final setting times in biomortars. Error bars represent standard deviation values of $\pm 12 \mathrm{~min}$ for the initial setting time and $\pm 20 \mathrm{~min}$ for the final setting time according to ASTM C191-04a.

Ersan et al. [18] incorporated bacteria, in the form of ACDC biogranules, with a dosage of $0.50 \% \mathrm{w} / \mathrm{w}$ cement into a mortar mixture that contains $2.00 \%$ calcium formate and $3.00 \%$ calcium nitrate. It was reported that ACDC has no significant influence on either of the setting times of the mixture when compared to the control mortar containing calcium formate and calcium nitrate. When the influences on setting times are considered, findings in this study enable us to extend the tolerable ACDC dosage in fresh biomortars up to $3.60 \% \mathrm{w} / \mathrm{w}$ cement $(2.50 \%$ of bacteria w/w cement).

Flow table results were evaluated in two different ways and presented in Table 5. At first, flow values of different mixtures were compared with the flow value of reference mortar. Secondly, the comparison was made considering the flow value of control mortar. Both comparisons revealed that when bacteria were added in the form of ACDC, addition of bacteria up to $2.00 \% \mathrm{w} / \mathrm{w}$ cement had no influence on workability of the mortar. However, addition of bacteria (as ACDC) more than $2.50 \% \mathrm{w} / \mathrm{w}$ cement negatively affected the rheology of mortars, decreasing the workability and thus resulting in poor compaction (Figure 4).

Either comparisons based on reference or control flow values led to contradictory conclusions. On the one hand, Bio-2.50\% and Bio-3.00\% mortars had flow values that corresponded to $96 \%$ and $91 \%$ of the reference flow (Table 5). Based on this comparison, both mortars were in the tolerable zone in terms of workability criteria given in NBN EN 1015-3. On the other hand, when compared to the control flow, flow values of Bio- $2.50 \%$ and Bio$3.00 \%$ mortars were $93 \%$ and $89 \%$, respectively, which led to elimination of $\mathrm{Bio}-3.00 \%$ due to its poor workability. When the flow table test results were combined with the compaction quality observations of different biomortars, it was found out that among the two approaches, comparisons with respect to control mixture were more meaningful in terms of determining the impact of biogranule dosage on workability, particularly for bacteria dosages higher than $2.00 \% \mathrm{w} / \mathrm{w}$ cement. Even though the flow values of Bio- $2.50 \%$ and Bio-3.00\% mortars were in the acceptable zone, good compaction of such mortars was not possible (Figure 4).

Table 5 Flow table results of different mixtures with respect to reference and control mortars ${ }^{1}$

\begin{tabular}{cccc}
\hline Mix names & $\begin{array}{c}\text { Flow } \\
(\mathbf{m m})\end{array}$ & $\begin{array}{c}\text { Flow } \\
(\% \text { vs R })\end{array}$ & $\begin{array}{c}\text { Flow } \\
(\% \text { vs C) }\end{array}$ \\
\hline Reference & 118 & 100 & 98 \\
Control & 121 & 103 & 100 \\
Bio-0.25\% & 116 & 98 & 96 \\
Bio-0.50\% & 124 & 105 & 103 \\
Bio-0.75\% & 125 & 106 & 103 \\
Bio-1.00\% & 123 & 104 & 102 \\
Bio-1.50\% & 123 & 104 & 102 \\
Bio-2.00\% & 121 & 103 & 100 \\
Bio-2.50\% & 113 & 96 & 93 \\
Bio-3.00\% & 108 & 91 & 89 \\
\hline
\end{tabular}

${ }^{1} \mathrm{R}$ : Plain mortar as reference, $\mathrm{C}$ : Control mixture contains $5 \%$ of calcium formate and $2 \%$ of calcium nitrate w/w cement. The percentages in biomortars represent wt bacteria/wt cement.

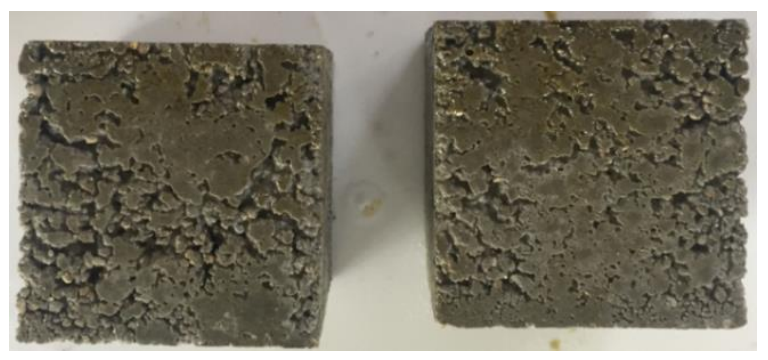

Figure 4 Compaction problems observed in Bio-2.50\% and Bio-3.00\% after demoulding.

Considering both workability and setting time results of different biomortars, the maximum tolerable biogranule dosage in bimortars could be determined as $3.60 \% \mathrm{w} / \mathrm{w}$ cement $(2.50 \%$ of bacteria w/w cement, in the form of ACDC). Biogranule dosages higher than $3.60 \% \mathrm{w} / \mathrm{w}$ cement are not recommended since they negatively affect the initial setting time and the compactability.

When organic matter is in contact with mortar matrix, set retardation occurs [19]. Microbial cells are composed of organic matter, and when cells die, the organic matter is released into the mortar matrix, which causes a delay in the setting time [18]. For instance, addition of an unprotected denitrifying microbial culture, Diaphorobacter nitroreducens, with a dosage of $0.5 \%$ $\mathrm{w} / \mathrm{w}$ cement into the mortar mix increased both initial and final setting time of mortar by 40 minutes [18]. The setting results were significant in terms of the self-protection capability of biogranules. Findings reveal that the addition of bacteria in the form of biogranules avoids possible set retardation effect of bacteria, especially at high dosages. 
The three stages that the loss of microbial healing agent is highly possible are during mixing, during the setting period and during the shrinkage of pores due to further hydration $[20,21]$. Yet, in this study, no set retardation was observed up to a bacteria dosage of $3.00 \% \mathrm{w} / \mathrm{w}$ cement, which confirmed that the bacteria inside the ACDC were not in contact with the mortar matrix whilst the mortar was setting. Therefore, it can be claimed that the mineral coating surrounding the biogranules was effective in protecting the bacteria during mixing and setting periods. The results were in accordance with the previous findings [3], which reported the survival of selfprotected ACDC after mortar incorporation.

\subsection{Compatibility of ACDC biogranules with hardened concrete}

Compressive strength tests were conducted on Day 3, Day 7 and Day 28 and the strength development of different mixtures were evaluated accordingly. There was no significant difference between the early age strengths of the reference specimen $(\sigma=29 \pm 4 \mathrm{MPa})$ and the control specimen $(\sigma=30 \pm 2 \mathrm{MPa})$. This observation was consistent with our previous findings [17]. Furthermore, increasing the ACDC content up to $2.86 \% \mathrm{w} / \mathrm{w}$ cement (Bio-2.00\%) did not cause any significant change in the 3-Day compressive strength of the mortar (Figure 5). However, further increase in the biogranule content (i.e. Bio- $2.50 \%$ and Bio-3.00\%) caused a decrease of $26 \%$ in 3-Day compressive strength values. Nonetheless, at the end of 7 days, all specimens had similar compressive strength values, which were around $40 \mathrm{MPa}$, and at the end of 28 days, the control mortar and biomortars even surpassed the reference mortar in terms of compressive strength. The 28-Day compressive strength of the reference mortar was recorded as $43 \pm 3 \mathrm{MPa}$ (Figure 5). The compressive strength values of control mortar and biomortars were similar to each other and varied around $56 \mathrm{MPa}$, which corresponds to a $30 \%$ increase in compressive strength.
The latter was consistent with our previous findings that addition of calcium formate and calcium nitrate with a dosage of $5 \% \mathrm{w} / \mathrm{w}$ and $2 \% \mathrm{w} / \mathrm{w}$, respectively, led to $20 \%$ increase in compressive strength with respect to the 28 days compressive strength of reference mortar [17]. Therefore, the observed strength increase could be attributed totally to the positive influence of chemical admixtures (i.e. calcium formate and calcium nitrate) on strength development. Therefore, it was safe to claim that biogranules produced in this study were compatible with the mortar matrix and did not influence the hardened properties of the mortar significantly. The negative influence of ACDC biogranules was observed only at high incorporation dosages (i.e. Bio- $2.50 \%$ and Bio-3.00\% where ACDC content were $3.60 \%$ and $4.30 \%$, respectively) and only on early age strength development. Yet, it is not clear whether the poor early age strength development was due to a high amount of biogranules or due to poor compaction of the corresponding specimens (Figure 4). Excepting Bio-2.50\% and Bio-3.00\% mortars, all the other biomortars showed decent strength development at early age.

Many researchers claim that direct addition of bacteria improves early age strength development due to MICP [22-24]. In this study, even though the nutrients and biogranules were added directly into the mixture, no significant influence was observed in early age strength development. There might be two reasons for this observation. Firstly, ACDC biogranules have a $\mathrm{CaCO}_{3-}$ $\mathrm{Ca}_{3}\left(\mathrm{PO}_{4}\right)_{2}$ coating which minimizes interaction of the core bacteria with the nutrient containing mortar matrix. Therefore, resuscitation of ACDC and MICP were unlikely whilst undergoing early age strength development. Secondly, the biogranules were produced at $\mathrm{pH}$ around 10 and further dried. In order to resuscitate the biogranules a $\mathrm{pH}$ value of around 10 is required and the $\mathrm{pH}$ of a mortar mix normally varies around 13.5, which might be the reason why no MICP occurred during the early age strength development. 


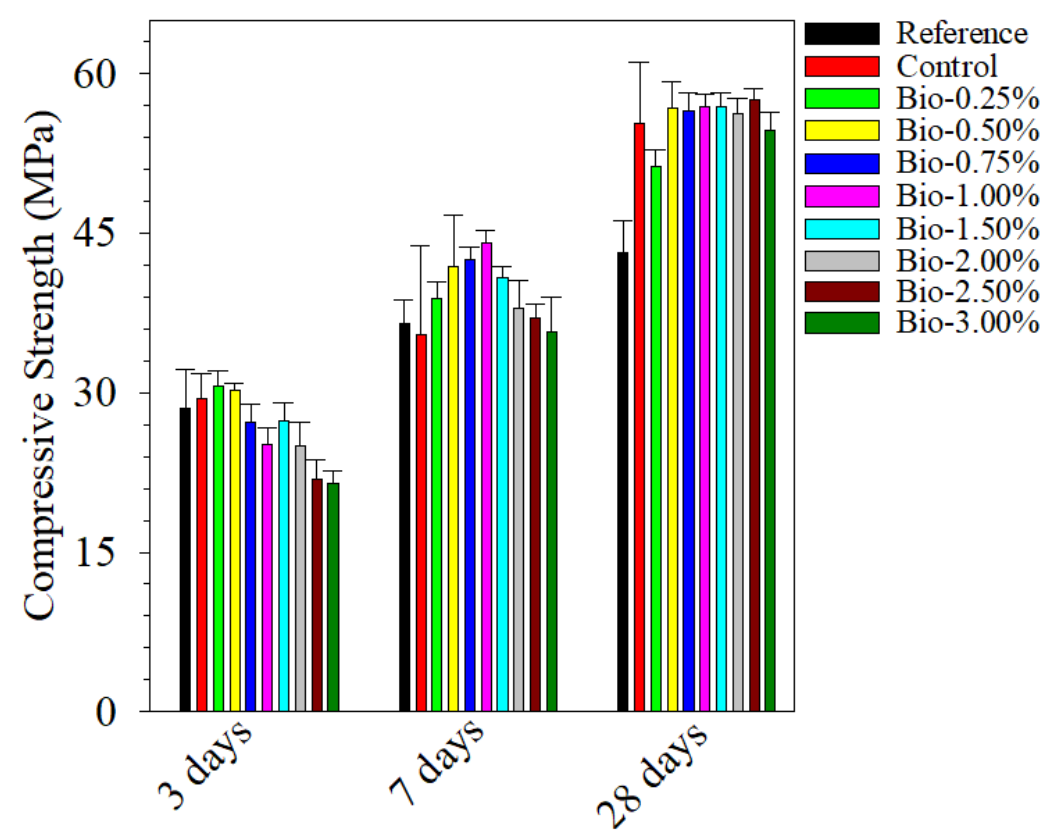

Figure 5 Compressive strength development in concrete with different amount of biogranules. Error bars represent the standard deviation of the mean $(n=3)$ Statistical significance was determined based on one-way ANOVA test $(\mathrm{p}=0.05)$.

\section{Conclusions}

Biogranules with an activated compact denitrifying core (ACDC) can be produced from old dry ACDC granules and the properties of produced fresh granules are similar to the old ones.

$\mathrm{A} \mathrm{CaCO}_{3}-\mathrm{Ca}_{3}\left(\mathrm{PO}_{4}\right)_{2}$ coating surrounding the $\mathrm{ACDC}$ biogranules minimizes the interaction between the mortar matrix and the core bacteria, and contributes to the biogranules' compatibility with mortar.

ACDC biogranules are compatible with fresh mortar and do not interfere with their setting and workability if their dosage in the mortar mixture is around $3.60 \% \mathrm{w} / \mathrm{w}$ cement (i.e. $2.50 \%$ of bacteria in the form of $\mathrm{ACDC}$ w/w cement) or less. At higher dosages, the initial setting time drops to 34 minutes, which is intolerable for site applications. Furthermore, workability and compaction quality decreases at higher dosages.

ACDC biogranules have no influence on strength development and they are compatible with the hardened mortar. Yet, if their dosage in the mortar mixture is around $3.60 \% \mathrm{w} / \mathrm{w}$ cement (i.e. $2.50 \%$ of bacteria in the form of ACDC w/w cement) or higher, then early age strength development is negatively affected and the 3-Day compressive strength of biomortar specimens decreases by $26 \%$.

Considering the influence of ACDC biogranules on both fresh and hardened properties of cement mortar, it can be stated that the tolerable biogranule content in biomortars is around $3.60 \% \mathrm{w} / \mathrm{w}$ cement (i.e. $2.50 \%$ of bacteria in the form of ACDC w/w cement). The best performance is achieved when the ACDC content is less than $3.60 \% \mathrm{w} / \mathrm{w}$ cement.

\section{Acknowledgments}

The research leading to these results received funding from the Scientific and Technological Research Council of Turkey (TUBITAK) under grant agreement no 118M768 (Determination of the optimum biogranule content in biogranule containing self-healing bioconcrete).

\section{References}

[1] Y.Ç. Erşan, E. Gruyaert, G. Louis, C. Lors, N. De Belie, N. Boon, Front Microbiol. 6, 1228 (2015).

[2] D. Gao, L. Liu, H. Liang, W.-M. Wu, Crit Rev Biotechnol. 31, 137-152 (2011).

[3] Y.Ç. Erşan, H. Verbruggen, I. De Graeve, W. Verstraete, N. De Belie, N. Boon, Cem Concr Res. 83, 19-30 (2016).

[4] Y.C. Ersan, D. Palin, S.B. Yengec Tasdemir, K. Tasdemir, H.M. Jonkers, N. Boon, N. De Belie, Front Built Environ. 4, 70 (2018).

[5] Y.Ç. Erşan, K. Van Tittelboom, N. Boon, N. De Belie, Sci Rep. 8, 14092 (2018).

[6] V. Wiktor, H.M. Jonkers, Cem Concr Compos. 33, 763-770 (2011).

[7] J. Wang, D. Snoeck, S. Van Vlierberghe, W. Verstraete, N. De Belie, Constr Build Mater. 68, 110-119 (2014).

[8] J. Wang, H. Soens, W. Verstraete, N. De Belie, Cem Concr Res. 56, 139-152 (2014).

[9] F.B. Silva, Up-scaling the production of bacteria for self-healing concrete application, $\mathrm{PhD}$ Thesis, 
Ghent University, (2015).

[10] F. Silva, N. De Belie, N. Boon, W. Verstraete, Constr Build Mater. 93, 1034-1041 (2015).

[11] Y.Ç. Erşan, E. Hernandez-Sanabria, N. De Belie, N. Boon, Cem Concr Compos. 70, 159-170 (2016).

[12] D. Palin, V. Wiktor, H.M. Jonkers, Biomimetics. 2, 13 (2017).

[13] E. Tziviloglou, V. Wiktor, H.M. Jonkers, E. Schlangen, Constr Build Mater. 122, 118-125 (2016).

[14] W. Khaliq, M.B. Ehsan, Constr Build Mater. 102, 349-357 (2016).

[15] M. Alazhari, T. Sharma, A. Heath, R. Cooper, K. Paine, Constr Build Mater. 160, 610-619 (2018). doi:10.1016/j.conbuildmat.2017.11.086.

[16] APHA, AWWA, WEF, Standard Methods for Examination of water and wastewater, 22nd Edition, (2012).

[17] Y.Ç. Erşan, Y. Akın, Optimizing nutrient content of microbial self-healing concrete, Proceedings of the Sixth International Symposium on Life-Cycle Civil Engineering (IALCCE 2018), 28-31.10.18, Ghent, Belgium, (2019).

[18] Y.Ç. Erşan, F.B. Silva, N. Boon, W. Verstraete, N. De Belie, Constr Build Mater. 88, 196-203 (2015).

[19] B. Khan, B. Baradan, Sci Vis. 8, 71-78 (2002).

[20] H.M. Jonkers, A. Thijssen, G. Muyzer, O. Copuroglu, E. Schlangen, Ecol Eng. 36, 230-235 (2010).

[21] Z.B. Bundur, A. Amiri, Y.C. Ersan, N. Boon, N. De Belie, Cem Concr Res. 98, 44-49 (2017).

[22] S. Ghosh, M. Biswas, B.D. Chattopadhyay, S. Mandal, Cem Concr Compos. 31, 93-98 (2009).

[23] N. Chahal, R. Siddique, A. Rajor, Constr Build Mater. 37, 645-651 (2012).

[24] Z. Basaran-Bundur, M.J. Kirisits, R.D. Ferron, Cem Concr Res. 67, 237-245 (2015). 